\title{
Making sense of the PIRLS 2006 results for South Africa ${ }^{1}$
}

\author{
HILARY JANKS University of the Witwatersrand
}

\begin{abstract}
Results on the PIRLS test in 2006 make it clear that South African educators need to examine the way in which they teach literacy in the Foundation phase. While the test gives a fair indication of what our children cannot do, it is less clear about what they can do. Mastery of decoding, for example, is assumed and children are tested on their ability to read lengthy texts and answer cognitively demanding questions. The test is therefore not a good indicator of whether learners can decode or not. By setting the kinds of skills demanded by PIRLS, against Freebody and Luke's roles of the reader, this article suggests that the problem with literacy learning in our schools is that too often students do not get much beyond decoding and basic comprehension. They are not taught to be text 'participants', text 'users' or text 'analysts'. Literacy interventions in schools need to prepare students to ask and answer middle and higher order questions on texts written in their home language if they are to move from learning to read to reading to learn.
\end{abstract}

\section{Introduction}

The Progress in International Reading Literacy Study (PIRLS) is an international systemic evaluation of literacy in home language. In 2006, 45 education systems in 40 countries participated. Most countries tested children in Grade Four. South African children were tested on two grades, Grade Four and Grade Five; at both levels South Africa's score was the lowest. It is not my intention in this paper, to repeat the details of the PIRLS report (Howie, Venter, van Staden, Zimmerman, Long, du Toit, Scherman and Archer, 2006) but to add a socio-cultural perspective on reading that might help us to make sense of the South Africa's dismal performance on PIRLS in 2006.

It is important to stress at the outset that I believe that there is merit in systemic evaluations as they help to draw attention to strengths and weaknesses in education which governments then have to address. It is not the fault of the

1 This discussion is based on the PIRLS 2006 Summary Report (Howie, Venter, van Staden, Zimmerman, Long, du Toit, Scherman and Archer, 2006).

READING AND WRITING

Vol 2, No 1, 2011 
researchers that their findings are rarely reported with a nuanced understanding of what the findings mean or that policy interventions do not address the root causes. One of the dangers, however, is that if repeated evaluations show little improvement, despite government interventions this is extremely demoralising for people working in the system, particularly teachers. As Steinbach suggested in her keynote address at the 2010 Reading Association of South Africa (RASA) conference: "To do the same thing over and over again and [to] expect a different result is the definition of insanity."

\section{Reading as a set of cognitive skills versus reading as a social practice}

One of the central debates in the literature on reading is whether reading is a skill or a social practice. This is a false dichotomy, an unhelpful form of binary thinking, as I will hope to show. If by skill, we mean cognition, then there can be little doubt that reading requires cognitive skills, such as recognition, (of letters and whole words), association (of letters and sounds), blending (combining sounds together to form words) and understanding (making sense of the marks on the page and how they make meaning). These are cognitive processes that take place in different parts of the brain as shown by new brain imaging technologies. Put simply, visual information is processed at the back of the brain, converted to sound in the head by the auditory centre of the brain (further forward and to the side of the brain) and conveyed to the front of the brain where meaning is processed. To do this the brain needs to create a new pathway which is developed by extensive practice. Moreover, for the brain to process information at the speed necessary for comprehension, the deciphering process needs to achieve automaticity. The miracle that happens when this is achieved is that fluent readers are able to read so effortlessly, that they have time to think their own thoughts in relation to those of the writers they are reading.

The more one is able to predict what a text is going to say, the less visual information (e.g., letters, words) one needs from the page (Smith, 1978). For example, if the last line on the page reads 'when he went to sleep his mother would sing him a lul-', it is possible to guess that the letters on the next page will complete the word 'lullaby', provided that you know the word. This is the principle on which the game 'Hangman' is based. Similarly, if you are travelling on the road and you know where you are going, you can 'read' the name of your destination on a road sign from far away just from the shape of the word. This helps us to understand why Goodman (1967) defined reading as a 'psycholinguistic guessing game.' His research on miscue analysis shows us that when children replace a word on the page with a different word, in most instances the word substituted has an equivalent meaning. The less visual 
information readers need, either because of their knowledge of the word or their knowledge of the context, the faster they can process meaning. This explains why it is so hard to understand texts in an unfamiliar discipline or unfamiliar language. The reader is so caught up in understanding the meaning of each new word, that he or she loses the thread of the sentence as a whole. If you do not have the vocabulary and don't understand the meaning of the words you are reading, reading is much harder and much slower.

In the South African PIRLS study, children were tested in

the language that children had been taught to read in and had been reading in for a minimum of four years. In South Africa, this manifested as the language of learning and teaching used by the school from Grade One (Howie, Venter, van Staden, Zimmerman, Long, du Toit, Scherman and Archer, 2006, 12).

Many South African children attend schools where the language of learning and teaching (LOLT) is different from their home language. Sometimes LOLT is a cognate language and sometimes LOLT and the child's home language are non-cognate languages. For example, for isiZulu children, isiXhosa is a cognate language but English and Afrikaans are not. Children may end up learning to read in a language they do not know and that is very different from learning in their own languages. Current research (Wolf, 2007; Snow, 2002) shows that children's knowledge of words and their meanings, developed through talking to them in the early years, is the best preparation for literacy. Many children in South Africa come to school without any knowledge of the words in the language they have to learn to read in. PIRLS is a home language test, taken by many children in an additional language. This does not exonerate South African education providers, as other children in other parts of the world are in similar situations, but it does suggest that we cannot expect our children to do as well as children writing in their home languages. And for African-language children in South Africa who are writing the test in their home languages, the test takes place in Grade Four or Grade Five, after they have switched from reading in their mother tongue to reading in English or Afrikaans. Children in the throes of a language/literacy switch cannot be expected to perform as well as children who are reading in their home language exclusively. PIRLS is not designed for children who have not been taught consistently to read in their home language. A home language literacy test such as PIRLS may be setting our children up for failure in the South African context. What the results do show with screaming clarity is that children in Grade Four are not ready for English as LOLT. They simply do not have the vocabulary, language and literacy skills for learning in English across the curriculum. This is not news: 
it was shown conclusively by Macdonald's (1991) Threshold Project Research, nearly twenty years ago.

I chose to begin with reading as a cognitive process because PIRLS is a test of reading skills and comprehension (cognition). But it is possible to read these results in relation to the different roles of the reader outlined in Freebody and Luke's (1990) work on the four roles of the reader, which include both the skills and the practices of readers. Freebody and Luke identify four roles for the reader: text decoder, text participant, text user and text analyst. Before using these roles to understand the PIRLS results it is important to explain them.

\section{Text decoder}

Text decoders can 'crack the code' (Freebody and Luke, 1990) of the texts they read: they can decipher the marks on the page. Decoding is the ability to know and recognise letters, to know the letter sound relationships and to understand how letters and their sounds combine to form words. Text decoding includes phonic, phonemic, sight word and reading aloud pedagogies. These work with lower order cognitive skills. Readers who can decode, without understanding, are able to read aloud; this is what Wardaugh (in Smith, 1978) refers to as 'barking at print'. Languages that have a one-to-one correspondence between letter and sound are easier to learn to decode (for example, Hebrew, Arabic and African Languages) and are known as phonetic languages. Languages that have more than one symbolic representation (letter combination) for the same sound (as in fun, fluffy and photo) or one symbolic representation for different sounds (for example, the letter $a$ which makes the sound $æ$ for sat; $e i$ for late; $a$ : for far; $\mathfrak{b}$ for swan and $ə$ in zebra) are known as phonemic languages. African languages and Afrikaans are phonetic; English is phonemic. Moving from literacy in a phonetic language to literacy in a phonemic language, like English, is difficult and confusing. This is further complicated by English's many vowel distinctions which are difficult to pronounce and hear in the early stages of learning English as an additional language, if your home language does not have these distinctions. Phonemic approaches, such as THRASS, rely on teachers being able to produce these distinctions and learners being able to hear them. This makes it a more suitable approach for enliteration in English home language than in English additional language.

The following story illustrates how difficult it is to hear and produce unfamiliar sound distinctions in a language. When South Africa introduced the National Credit Act (2005) the government also introduced debt counselling. Fairly quickly the rumour spread that the government had agreed to debt cancelling. Highly articulate radio presenters when trying to make the distinction 
could be heard to say 'cunselling' / $\Lambda$ for both 'counselling' /ar/and 'cancelling' $/ æ /$, using a vowel sound midway between /aø/ and /æ/. This increased the confusion. Similarly, English speakers learning to speak an African language often experience great difficulty hearing and producing unfamiliar consonant sounds and tonal variations.

Many South African children can decode both words and pictures, but this is not all that is tested by PIRLS. PIRLS assumes that children have learnt these lower order reading skills and the questions asked require higher order skills than decoding. If decoding is all that children can do, they will not manage the PIRLS test. Conversely, if children do badly on the PIRLS test it does not mean that they cannot decode, the skill that many people equate with 'reading. But reading is much more than the ability to turn the squiggles on the page into sound - aloud or silently in one's head. Until such time as automaticity in decoding is achieved, readers are still learning to read.

\section{Text participant}

Text participants make meaning from texts. While this includes comprehension, it is much more than simply understanding the meaning of the words and images on the page. This role requires readers to understand what the text is both saying and inferring. However, in addition to taking meaning from texts, readers also have to bring meaning to texts, that is, they have to be active not passive readers. Making sense of a text, requires learners to relate the meanings of texts to what they already know. Only in this way can the meanings of texts be assimilated. This ability is essential for reading to learn. Learners need practise interacting with texts and discussing them in relation to their own experiences. The need to talk about texts: they need to talk about what they agree with and disagree with; they need to talk about what the text reminds them of, they need to imagine how the text could have been written differently, perhaps with a different ending; they need to act out the stories and draw images that show how they understand the text; they need to spend time with a text. Too often in classrooms, students read the story and that is it. Children's stories need to be revisited, explored from the point of view of the different characters, examined for details in the images, or simply read again and again for enjoyment. Factual texts, such as books on transport or the weather, enable text participants to work with what is new and old information. They also create possibilities for children to imagine: imagine what kind of transport there will be when the world runs out of oil; what life will be like when the weather is much hotter. 


\section{Text user}

Text users read a wide range of texts for a variety of purposes, often. It is important that young readers and writers have a very good understanding of what literacy is for, if they see little evidence of it in the neighbourhood where they live. In local communities where there are few books, or newspapers, or magazines, or billboards or food packaging in their languages, (apart from the Bible) literacy tends not to be an everyday practice. This is compounded by limited library services and inadequate access to books of all kinds in schools. In some communities, people who can read, including teachers, often prefer not to, because reading in an additional language is just too hard. Reading and writing become tied in people's minds to the worlds of work and school and are rarely associated with pleasure. As a result many students, particularly in rural areas, are exposed to a limited range of text types and they do not always have access to literacy role-models. Without a visible need for literacy, it is hard to make it desirable. Teachers have to find the literacy practices that are embedded in local communities and build on these. A love for TV can be turned into writing mini-episodes; love for cartoons can lead to the reading of comics; love for cars can be turned into working with catalogues and comparing brands; enjoyment of football can lead to reading the sports pages of newspapers and sport magazines. Dyson $(1992,2003)$ shows convincingly how children's engagement with popular culture acts as a spur for reading, writing and drawing. The one literacy practice that is widespread in South Africa where there is 95\% (Brown and Czerniewicz, 2010) cell phone penetration is text messaging. Schools need to think carefully how to harness widespread desire for new technologies as a means of turning children into text users. Consuming and producing texts are two sides of the same coin. For example, anyone who has taken a photograph has a better understanding of concepts such as framing, focus, shots and angles than someone who has never looked through a view finder. Reading and writing similarly inform one another.

Without a nuanced understanding of what it is possible to infer from the PIRLS report, we might choose the wrong literacy intervention. If, as I will argue, the PIRLS test items require high level meaning making skills, it will not help to provide schools with materials that improve the teaching of phonics and deciphering but do not invite students to make inferences from what they are reading, to analyse and synthesise meanings and to evaluate texts.

\section{Text analyst}

Analysts are able to evaluate texts in relation to their social effects. They understand that texts are positioned and positioning as well as how they work to 
persuade readers. They recognise that texts are not neutral but are constructed by their writers to inform and influence and readers. Analysts pay attention to the ways in which texts shape our identities - what we think and believe as well as what we value and do. Analysts examine the writer's choices to see whose side he or she is on and to work out who benefits as a result. Who is included? Who is excluded? Who is favoured and who is not? What is shown as natural and inevitable or, on the other hand, as the result of human action? What is portrayed as normal and deviant behaviour? Who decides? Who speaks? Analysts read critically to understand the power relations that are evident in everyday texts. They want to know whose interests are served by the text in order to evaluate its social effects.

Most teachers and curriculum writers in South Africa think that this is too hard for general education. Some even think that this should be left to Higher education. However, research has shown that very young children can do this kind of analysis. In Australia, Jennifer O'Brien (2001) used everyday texts in her classroom of 5 to 8 year olds. Her work with mothers' day cards is emblematic. The following brief summary gives the flavour of her project. She began by asking the children to discuss in groups what they thought their mothers would like for mothers' day and in a group report-back gathered all their ideas. Then she sent the children home to do some research: they had to find out what their mothers wanted for mothers' day. The two sets of answered were compared and the difference and similarities were discussed. Then she handed out mothers' day catalogues and invited children to tackle the following kinds of questions simply by reading the images.

What do catalogues show that mothers want?

Are these the same or different from what mothers say they want? Why do you think mothers say they want cards, flowers picked from the garden and hugs, while catalogues say they want jewellery, perfume and washing machines?

Do the mothers in the catalogue look like your (Vietnamese) mothers? How are the mothers in the catalogue different from your mothers? The children said that the catalogue mothers were young, thin, pretty, made-up, Anglo and so on. Can you explain why this is?

How would you like to change this catalogue? Why?

And then, when Fathers' day followed, the children were asked to compare what catalogues said that mothers want with what they said fathers want, leading to a discussion of the social construction of gender. 
Children do not have to be able to read to analyse the catalogues. If we teach them how to ask critical questions about the representations of mothers in pictures, we provide them with an orientation to text that can be transferred to their reading of print. Vasquez' (2004) award-winning book Negotiating Critical Literacy with Young Children demonstrates convincingly the possibility of doing this kind of work with even younger children, aged 3 to 5 years old.

\section{Using the four roles of the reader to make sense of the PIRLS results}

In Chapter 8 of the PIRLS 2006 Summary Report (Howie et al, 2006: 39), Long and Zimmerman examine the school curriculum and the organisation for teaching reading. Their findings are based on interviews with principals, who were asked, "At which Grade do the following reading strategies first receive a major emphasis in instruction in your school?" Twelve reading strategies based on current reading theories were listed for consideration (p. 41).

They identified twelve strategies for reading: 1 . Knowing letters; 2 . Knowing letter-sound relationships; 3 . Reading words; 4 . Reading isolated sentences; 5. Reading connected text; 6 . Identifying the main idea of the text; 7 . Explaining or supporting understanding of the text; 8 . Comparing text with personal experience; 9. Comparing different texts; 10 . Making predictions about what will happen next; 11. Making generalisations and inferences; 12 . Describing the style and structure of the text.

I have assigned these strategies to the different roles of the reader in Table 1 below.

Table 1: Text strategies aligned with the roles of the reader

\begin{tabular}{|c|c|}
\hline $\begin{array}{c}\text { Roles of the reader } \\
\text { (Freebody and Luke 1990) }\end{array}$ & $\begin{array}{l}\text { Strategies for reading (Long and Zimmerman, } \\
\qquad 2006)\end{array}$ \\
\hline TEXT DECODER & Knowing letters (1) \\
\hline $\begin{array}{l}\text { Cracks the code of the text } \\
\text { with knowledge of phonics, } \\
\text { phonemics and sight words. }\end{array}$ & $\begin{array}{l}\text { Knowing letter-sound relationships (2) } \\
\text { Reading words (3) } \\
\text { Reading isolated sentences (4) } \\
\text { Reading connected text (5) }\end{array}$ \\
\hline
\end{tabular}




\begin{tabular}{|c|c|}
\hline $\begin{array}{c}\text { Roles of the reader } \\
\text { (Freebody and Luke 1990) }\end{array}$ & $\begin{array}{l}\text { Strategies for reading (Long and Zimmerman, } \\
\qquad 2006)\end{array}$ \\
\hline TEXT PARTICIPANT & Identifying main idea (6) \\
\hline $\begin{array}{l}\text { Makes meaning by taking } \\
\text { meaning from and bringing } \\
\text { meaning to texts. Relates } \\
\text { meanings in the text } \\
\text { own ideas, values and } \\
\text { experiences. }\end{array}$ & $\begin{array}{l}\text { Explaining or supporting understanding (7) } \\
\text { Comparing with personal experience (8) } \\
\text { Making predictions (9) } \\
\text { Making generalisations and inferences (11) }\end{array}$ \\
\hline $\begin{array}{l}\text { TEXT USER } \\
\text { Range of texts used for } \\
\text { different purposes }\end{array}$ & $\begin{array}{l}\text { Comparing different texts (for different } \\
\text { purposes: literary and information texts) (9) } \\
\text { Describing style and structure (12) }\end{array}$ \\
\hline TEXT ANALYST & Not included in the 12 strategies \\
\hline $\begin{array}{l}\text { The social effects of text - } \\
\text { who benefits? }\end{array}$ & $\begin{array}{l}\text { Evaluation questions are not included in the } \\
12 \text { strategies: Explaining the possible social } \\
\text { effects of texts. Explaining who is included } \\
\text { and excluded. Explaining who benefits and } \\
\text { who is disadvantaged. Evaluating whether the } \\
\text { text is fair or not. } \\
\text { Explaining the effects of word, image and } \\
\text { style choices in creating these social effects. } \\
\text { (12) } \\
\text { Explaining what the text wants the reader to } \\
\text { believe and why. } \\
\text { What if questions that invite students to } \\
\text { consider alternative possibilities. }\end{array}$ \\
\hline
\end{tabular}




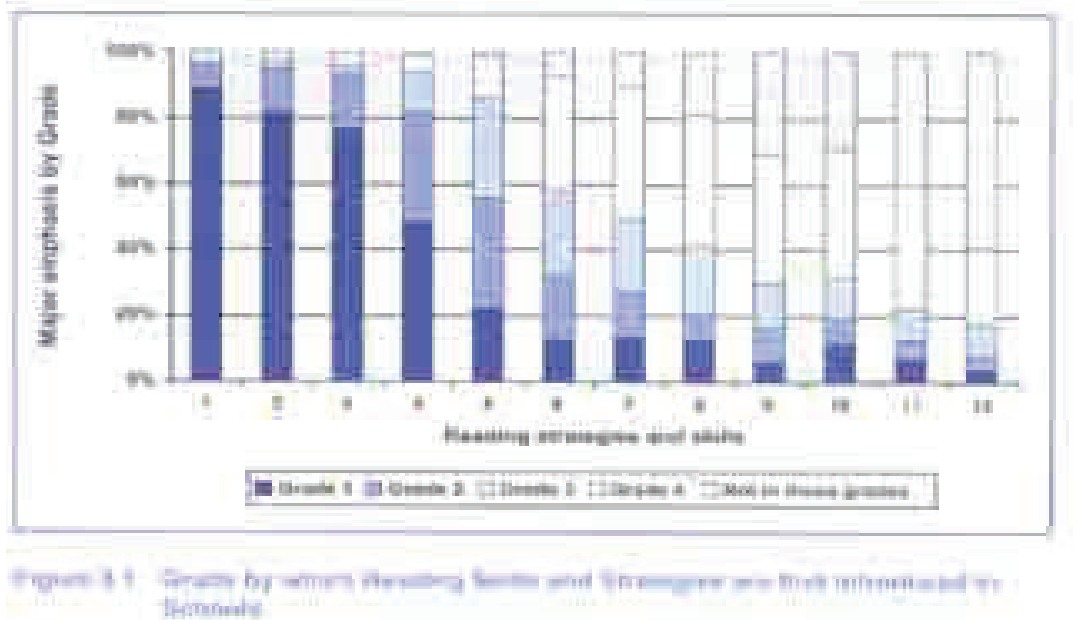

Figure 8.1: in Howie et al's (2006) summary report shows the grade at which these strategies are first introduced in schools.

What this figure makes clear is that the focus in the early years is on children as text decoders who can move from letter recognition to the reading of connected text (Strategies 1-5). The strategies that are more cognitively demanding tend to be introduced, if at all, in Grades Three or Four. There is some evidence of readers as meaning takers but not meaning makers; as readers they are expected to comprehend the text. Most schools at some stage during the Foundation years ask readers to identify the main idea of the text (6). However $20 \%$ of schools do not invite students to relate what they are reading to their personal experience (8); $30 \%$ of schools do not require children to compare texts or to predict what will happen $(9-10) ; 40 \%$ do not require students to make generalisations and inferences (11) and a massive $60 \%$ of schools pay no attention to describing the structure and style of texts (12).

The more demanding cognitive strategies, if they are taught at all occur towards the end of the Foundation phase. There is very little evidence of children as text users or as text analysts. There are only two strategies that require students to be text users and there is little evidence of these strategies being introduced to students before Grade 4. Children as text analysts are not even on the map. This goes a long way to explaining why South Africa's PIRLS scores are so low. Moreover, Long and Zimmerman (2006) show a correlation between higher scores and the introduction of the more cognitively demanding strategies from Grade One. What we do not need in Grades One and Two is more focus on phonics, phonemics and word recognition but rather an emphasis on active engagement with how different kinds of texts make meaning, what they mean, 
and how readers relate the meanings in texts to their own life worlds. Learners need to be invited to imagine, and predict, and infer consequences. We should not underestimate what young children are capable of doing.

Vasquez' (2003) Getting Beyond "I Like the Book", written with teachers, provides practical ways of extending students' engagement with books. What is important is that teachers provide 'sustained time to linger with a book'. Lee Hefferman provides a model for developing children's ability to talk about books and to become text participants.

\section{Lee's Six sessions for Working with a Picture Book}

Session 1: Read aloud

Read the book out loud and give students ample time to make connections, comment and ask questions.

\section{Session 2: Picture Walk}

The book is revisted for a second time with a picture walk through the text. During this walk students talk about what they remember about the book from the pictures.

\section{Session 3: Small groups conversations}

Why do you think people should or should not read the book?

What surprised you about this book?

What questions do you have about the book?

What topics from your own life connect to the book?

Write one or two statements from someone whose perspective is represented in the book.

Write one or two statements from someone whose perspective is not represented in the book.

Each group marks the statements and questions that generated a lot of discussion with a star.

Session 4: Whole group meeting

The class meets as a whole to discuss the starred questions. 


\title{
Lee's Six sessions for Working with a Picture Book
}

\author{
Session 5: Choose an illustration
}

The group discusses the illustration from the book that best represents the conversations about it.

\section{Session 6: Notebook writing}

Each student writes a couple of pages in his or her notebook about the writing topics noted on the response sheet during Session 2. (Vasquez, 2003, 37, adapted).

Vasquez (2003) also shows how teachers can teach children to become text analysts by focussing on social issues (Chapter 3 ) and using children's literature to unpack social issues in the school community (Chapter 4). The book concludes with annotated bibiliographies of books for children that explore social issues (Appendix B), that depict social action (Appendix C) and that create space for children to talk about issues of racism, power and control (Appendix D). The cognitive demand of this kind of approach to reading is far removed from the hunt-through-the-text-to-find-information approach typical of many South African classrooms.

But cognitive strategies are not enough, if literacy practices are not embedded in children's lives. If children are not helped to become text users then they will not be exposed to the full range of text types and the different ways in which they are shaped for different social purposes. Invitations are different from catalogues and they are both different from stories and songs. Children need to be given opportunities to explore these and other texts, to discuss their differences, and to produce a range of texts themselves. Given the freedom to become text participants, text users and text analysts, in relation to reading and writing, children are more likely to discover the pleasures of literacy and the desire needed to overcome the challenge of cracking the code.

\section{References}

Brown, C. and Czerniewicz. L. 2010. Debunking the "digital native": beyond apartheid, towards digital democracy. In Journal of Computer Assisted Learning. 26(5): 357-369.

Freebody, P. and Luke, A. 1990. Literacies programmes: debates and demands in cultural contexts. Prospect: A Journal of Australian TESOL, 11: 7 - 16.

Dyson, A. 1997. Writing superheroes, contemporary childhood, popular culture and classroom literacy. New York: Teachers College Press. 
Dyson, A. and Geneshi, C. 2003. The brothers and sisters learn to write, popular literacies in childhood and school cultures. New York: Teachers College Press.

Goodman, K. 1967. Reading, A psycholinguistic guessing game. Journal of the Reading Specialist, May: 126-135.

Howie, S., Venter E., van Staden, S., Zimmerman, L., Long, C., du Toit, C., Scherman, V. and Archer, E. 2006. PIRLS 2006 Summary Report. Pretoria: University of Pretoria.

O'Brien, J. 2001. Children reading critically. In Negotiating Critical Literacies in Classrooms, B. Comber, And A. Simpson. Mahwah: Lawrence Erlbaum.

Macdonald, C. With Burroughs, E. 1997. Eager to Talk and Learn and Think. Cape Town: Maskew Miller Longman.

Smith, F. 2004. Understanding Reading. London: Routledge.

Snow, C. 2002. Reading for Understanding. Science and Technology Institute (Rand Corporation, United States).

Vasquez, V. 2004. Negotiating Critical Literacies with Young Children. Mahwah: Lawrence Erlbaum.

Vasquez, V. with Muise, M., Adamson S., Hefferman, L., Chiola-Nakai, D. and Shear, J. 2003. Getting beyond "I Like the Book". Newark: International Reading Association.

Wolf, M. 2007. Proust and the Squid: The Science of the Reading Brain. New York: Harper. 
